\title{
The Current Status of Parasitic Diseases in Japan
}

\author{
Fukumi NaKamura-UchiYama, Kenji Hiromatsu, Kenji Ishiwata, \\ Yukiko SAKAMOTO and Yukifumi NAWA
}

\begin{abstract}
In Japan parasitic diseases have been considered to be successfully controlled in the last 30 years. However, some parasitic diseases, such as food-borne zoonoses and/or larva migrans, are emerging and/or re-emerging in Japan. Furthermore, imported parasitic diseases like malaria are also gradually increasing. Unfortunately accurate numbers of parasitic diseases other than echinococcosis, malaria, amebiasis, giardiasis, or cryptosporidiosis are obscure in Japan because of the lack of a legal registration system. Since symptoms and diagnostic imaging patterns of parasitic diseases are non-specific and have similarities with other infectious diseases or cancer, parasitic diseases are sometimes overlooked or left misdiagnosed. In this review, the current status of parasitic diseases in Japan is briefly summarized based on the analysis of the accumulated cases seen in our department. We also outline the clinical features, differential diagnosis and treatment of representative parasitic diseases for the better understanding and management of the parasitic diseases in Japan.
\end{abstract}

(Internal Medicine 42: 222-236, 2003)

Key words: food-borne zoonoses, emerging/re-emerging diseases, larva migrans, imported parasitoses, differential diagnosis, orphan drugs

\section{Have Parasitic Diseases Really Been Eradicated in Japan?}

In the immediate post-World War II period, Japan was regarded as "Paradise of Parasites" because of spreading of soil-transmitted parasitoses such as ascariasis, trichuriasis and hookwoom disease. After a nationwide campaign, mass screening, treatment and prevention of parasitic diseases under the Parasite Control Law, the egg detection rates of Ascaris and hookworm in stool examination decreased from $59.6 \%$ and $4.5 \%$ in 1950 to $<0.1 \%$ and $0 \%$ in 1980 s, respec- tively. Some other helminthes that cause serious diseases such as schistosomiasis, domestic malaria and lymphatic filaria were also successfully eradicated by the middle of 1980s (1). Such successful eradication/control of parasitic diseases resulted in the termination of the Parasite Control Law in 1994 (1). Although the new Infectious Diseases Control Law was applied in 1999, only five parasitic diseases, four protozoan diseases (amebiasis, cryptosporidiosis, giardiasis and malaria) and one helminthiasis, echinococcosis are assigned as the notifiable parasitoses. Now not only the public but also medical professionals tend to consider parasitoses as a disease of the past. However, the number of patients having parasitic diseases referred to and diagnosed in our laboratory has been increasing every year (Fig. 1A) (2, 3). In agreement with our experience, Arizono has recently reported that more than 1,000 case reports of parasitic diseases were found in the database, Igaku-ChuoZasshi (Japana Centra Revuo Medicina) between 1995 and 1999 (4). In this review, we summarize the current status of parasitic diseases in Japan together with clinical features, diagnosis and treatment of clinically important and frequently experienced parasitoses.

\section{Current Status of Parasitic Diseases in Japan}

It is difficult to grasp the concrete number of parasitic diseases, especially those of helminthiases in Japan due to the changeover of legislation for infectious diseases. We implemented the immuno-serological tests for diagnosis of parasitic diseases in 1986. Multiple-dot ELISA method (Fig. 1B), which was introduced in 1991 for the primary screening to detect parasite-specific antibodies, has enabled us to respond faster than before to the attending physicians. The number of samples referred to our laboratory has drastically increased since 1995, and reached over 400 new samples and 200 samples for follow-up per year in 2000 and 2001. Among those consultations, about $40 \%$ of patients were diagnosed as having parasitoses (Fig. 1A). The incidence of each parasitic disease referred to and diagnosed in our laboratory is summarized in Table 1.

The majority of cases diagnosed in our laboratory are

From Department of Parasitology, Miyazaki Medical College, Miyazaki Reprint requests should be addressed to Dr. Yukifumi Nawa, Department of Parasitology, Miyazaki Medical College, Kiyotake, Miyazaki 889-1692 


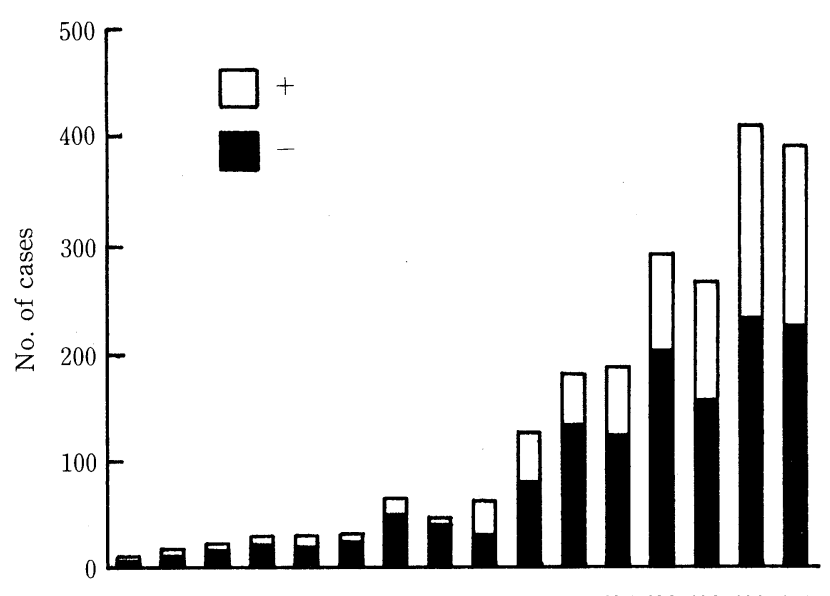

'86 '87 '88 '89 '90 '91 '92 '93 '94 '95 '96 '97 '98 '99 '00 '01

$$
\text { Year }
$$

Multiple-dot ELISA Test for Parasitic Diseases

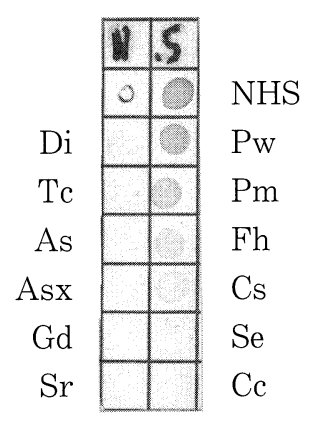

Serum

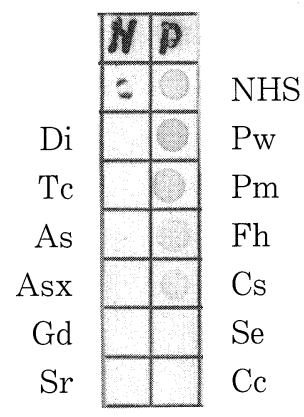

Pleural Effusion
$\mathrm{B}$

Figure 1. Number of cases referred to our laboratory (A) and multiple-dot ELISA for parasitic diseases (B). Recently about $40 \%$ of the cases were diagnosed as having parasitoses (A). The patient's serum and pleural effusion showed a high titer of IgG against Paragonimus westermani with some cross-reactions to other trematode antigens (B). Pw: $P$. westermani, Pm: P. miyazakii, Fh: Fasciola hepatica, Cs: Clonorchis sinensis, Se: Spirometra erinaceieuropaei, Cc: Cysticercus cellulosae, Di: Dirofilaria immitis, Tc: Toxocara canis, As: Ascaris suum, Asx: Anisakis simplex, Gd: Gnathostoma doloresi, Sr: Strongyloides ratti. (b: Reprinted from Clinics in Chest Medicine, 23, Nakamura-Uchiyama $F$ et al, "Paragonimiasis: A Japanese perspective", 409-420, Copyright 2002, with permission from Elsevier Science).

food-borne helminthiasis, especially of zoonotic nature and/ or larva migrans as indicated in Table 1. Among them, Ascaris suum-VLM (visceral larva migrans) and paragonimiasis are the two foremost parasitic diseases. The majority of these cases were from Kyushu (2). Paragonimiasis is a reemerging disease in Kyushu a previously heavily endemic
Table 1. Incidence of Various Parasitic Diseases Diagnosed in Our Laboratory during 1999-2001

\begin{tabular}{|c|c|c|}
\hline \multirow[t]{3}{*}{ Protozoa } & Giardiasis & 1 \\
\hline & Entoamebiasis & 3 \\
\hline & Malaria & 5 \\
\hline \multirow[t]{5}{*}{ Trematoda } & Paragonimiasis & 99 \\
\hline & Fascioliasis & 10 \\
\hline & Schistosomiasis & 4 \\
\hline & Clonorchiasis & 1 \\
\hline & Metagonimiasis & 1 \\
\hline \multirow[t]{6}{*}{ Cestoda } & Diphyllobothriasis & 3 \\
\hline & Diplogonoporiasis & 2 \\
\hline & Taeniasis saginata & 2 \\
\hline & Sparganosis & 7 \\
\hline & Cysticercosis & 5 \\
\hline & Echinococcosis & 2 \\
\hline \multirow[t]{14}{*}{ Nematoda } & Ascariasis lumbricoides & 8 \\
\hline & Strongyloidiasis & 16 \\
\hline & Hookworm disease (human origin) & 3 \\
\hline & Trichuriasis & 3 \\
\hline & Enterobiasis & 2 \\
\hline & Thelaziasis & 1 \\
\hline & Lymphatic filariasis & 2 \\
\hline & Angiostrongyliasis & 7 \\
\hline & A. suum-/ T. canis-VLM & 170 \\
\hline & Anisakiasis & 19 \\
\hline & Gnathostomiasis & 42 \\
\hline & Spiruroid larva migrans & 3 \\
\hline & Hookworm disease (animal origin) & 9 \\
\hline & Dirofilariasis & 10 \\
\hline \multirow[t]{3}{*}{ Others } & Tick bite & 5 \\
\hline & Myasis & 3 \\
\hline & Scabies & 1 \\
\hline
\end{tabular}

Bold-face: Food-borne zoonoses, $\square$ : Larva migrans.

area of this disease (5). Meanwhile A. suum-VLM is an emerging disease in this area probably due to recent concentration of cattle, pig and poultry farms in southern Kyushu (6). Although imported parasitic diseases are rather rare in our data, we encountered some patients assumed to be infected during traveling overseas, such as giardiasis, malaria, cysticercosis and creeping eruption due to percutaneous infection with larval dog hookworm. It should also be pointed out that classical soil-transmitted parasites are still present to cause diseases in Japan.

In contrast to our data, protozoan diseases accounted for about $45 \%$ of total case reports of parasitoses from an analysis of the Japanese database, Igaku-Chuo-Zasshi, during 1995 and 1999 (Table 2) (4). All patients with malaria were infected during travel in tropical and subtropical countries. However, patients with other protozoan diseases seemed to be infected in Japan. In fact, amebiasis is currently epidemic in male homosexuals and institutionalized people; few cases are imported (7). Two water-borne outbreaks of cryptospori- 
Table 2. Numbers of Parasitic Diseases Case Reports in Japan Found in Japana Centra Revuo Medicina Database (1995-1999) (4)

\begin{tabular}{|c|c|c|c|c|c|c|c|}
\hline \multicolumn{2}{|l|}{ Protozoa } & \multicolumn{2}{|c|}{ Trematoda } & \multicolumn{2}{|l|}{ Cestoidea } & \multicolumn{2}{|c|}{ Nematoda } \\
\hline Entoamoeba & 167 & Schistosoma & 90 & Diphyllobothrium & 62 & Anisakis & 99 \\
\hline Pneumocystis & 154 & Paragonimus & 49 & Sparganum & 31 & Dirofilaria & 54 \\
\hline Toxoplasma & 102 & Clonorchis & 16 & Taenia solium & 27 & Ascaris & 52 \\
\hline Plasmodium & 94 & Fasciola & 13 & Echinococcus & 21 & Strongyloides & 48 \\
\hline Acanthamoeba & 35 & & & Taenia saginata & 6 & Toxocara & 27 \\
\hline Giardia & 14 & & & Diplogonoporus & 5 & Gnathostoma & 23 \\
\hline Leishmania & 13 & & & & & Spirurina & 19 \\
\hline Amebic encephalitis & 10 & & & & & Ascaris suum & 16 \\
\hline Isospora & 6 & & & & & Hookworms & 11 \\
\hline Trichomonas & 6 & & & & & Enterobius & 10 \\
\hline \multirow[t]{3}{*}{ Cryptosporidium } & 5 & & & & & Angiostrongylus & 8 \\
\hline & & & & & & Trichuris & 8 \\
\hline & & & & & & Trichinella & 5 \\
\hline Total & 606 & & 155 & & 152 & & 393 \\
\hline
\end{tabular}

diosis are still fresh in our mind $(8,9)$. Cryptosporidium oocysts and Giardia cysts were detected in raw and even in filtrated water in Japan (10). Among the helminthiases in this database, most are food-borne zoonoses and/or larva migrans, as seen in our data. It should be emphasized again that classical parasites such as Ascaris and hookworm continue to exist at a low level in Japan.

One of the notable findings from the analyses of our data and the literature survey from the databases is that the majority of helminthiasis is food-borne zoonoses. This trend may be reflecting preferential food-habits of the Japanese consuming raw materials as "Sushi" or "Sashimi" with "Soy sauce". For example anisakiasis and diphyllobothriasis are highly prevalent in Japan. Creeping eruption and acute abdomen due to Spirurina Type X larvae infection after eating small scintillant squids has recently emerged (11). In addition to marine fishes, crustaceans and shellfishes, freshwater fishes and wild animal meat are also served as "Sushi" or "Sashimi". In this aspect, it is interesting that more than 70\% of the recent paragonimiasis cases were coming from eating raw wild boar meat, though freshwater crabs have been considered the important source of Paragonimus infection (5). The major source of Gnathostoma sp. infection is freshwater fishes such as brook trout, imported loach or snakehead fish (12). In addition, snakes are also important reservoir hosts of G. doloresi as well as Spirometra erinaceieuropaei $(13,14)$. Some gnathostomiasis and sparganosis patients were infected by eating snakes as "Sashimi", since they believed in tonic effects of raw snake meat (15). Chicken/cattle liver is an important source for infection with A. suum- and Toxocara canis-VLM in middle-aged men (16). Related to this, some Japanese ingest actively raw materials as medicine. For example, freshwater crab juice given for asthma treatment caused paragonimiasis, and ingestion of raw slugs for treatment of lumbago or mineral supplement caused angiostrongyliasis (17-19).

The increase in number of imported parasitoses such as malaria and giardiasis is directly related to the increasing number of overseas travelers. However foreign foods contaminated by parasites are also imported in Japan. Recently, we encountered paragonimiasis cases among foreigners living in Japan. The sources of their infection were imported Chinese crabs served in a Chinese restaurant or bottled drunken (liquor-soaked) crabs brought out from China as a souvenir (20). Food-borne outbreaks associated with parasites have been reported in the world (21). We may be seeing more patients with food-borne parasitic diseases in Japan with the increment of food trading and the popularization of ethnic dishes.

In summary, parasitic diseases currently seen in Japan are characterized as follows:

1) Food-borne diseases and/or larva migrans related to Japanese food-habits: anisakiasis, diphyllobothriasis, gnathostomiasis, sparganosis and other diseases.

2) Emerging/Re-emerging diseases: cryptosporidiosis, echinococcosis, spiruroid larva migrans, A. suum-VLM, paragonimiasis and other diseases.

3) Gradually increasing imported parasitoses: malaria, giardiasis and cysticercosis.

4) Persistent occurrence of classical soil-transmitted parasitoses: ascariasis lumbricoides, hookworm and other diseases.

\section{Clinical Features of Parasitoses: Symptoms, Diagnosis and Treatment}

In the analysis of the current trends of parasitic diseases in Japan, we have noticed that a few malaria patients are still dying almost every year because of delayed and/or inadequate diagnosis (22). Furthermore, parasitic zoonoses are 
Table 3. Clinical Symptoms and Possible Parasitoses, Diagnosis and Treatment

1. Fever

\begin{tabular}{|c|c|c|c|c|}
\hline Possible parasitoses & Findings & Remarks & Diagnosis & Treatment \\
\hline Malaria & & $\begin{array}{l}\text { Travel abroad } \\
\text { Anemia } \\
\text { Kidney failure/CNS involvement }\end{array}$ & Blood smear & Vary $^{\mathrm{a}}$ \\
\hline \multicolumn{5}{|c|}{ 2. Abdominal symptom-Diarrhea } \\
\hline Possible parasitoses & Findings & Remarks & Diagnosis & Treatment \\
\hline Entoamebiasis & $\begin{array}{l}\text { Mucous and bloody stool } \\
\text { Loose passage/Watery stool }\end{array}$ & STD, Immunodeficiency (HIV) & $\begin{array}{l}\text { Stool examination } \\
\text { (trophozoites) }\end{array}$ & $\begin{array}{l}\text { MNZ } \\
\text { (1,000 mg/day for } 10 \text { days })\end{array}$ \\
\hline Giardiasis & \multirow{7}{*}{ Loose passage/Watery/Fatty stool } & $\begin{array}{l}\text { Travel abroad, Water supply } \\
\text { Ingestion of imported fruits }\end{array}$ & $\begin{array}{l}\text { Stool examination } \\
\text { (cysts) }\end{array}$ & $\begin{array}{l}\text { MNZ } \\
\text { ( } 750 \mathrm{mg} / \text { day for } 7-10 \text { days) }\end{array}$ \\
\hline Cryptosporidiosis & & Immunodeficiency (HIV) & $\begin{array}{l}\text { Stool examination } \\
\text { (oocysts) }\end{array}$ & Symptomatic treatment \\
\hline Strongyloidiasis & & $\begin{array}{l}\text { Immunodeficiency (ATL, HIV) } \\
\text { Eosinophilia } \\
\text { Origin/Habitat (Okinawa) }\end{array}$ & $\begin{array}{l}\text { Stool examination } \\
\text { (larvae) } \\
\text { Immunodiagnosis }\end{array}$ & $\begin{array}{l}\text { TBZ } \\
(30-50 \mathrm{mg} / \mathrm{kg} / \text { day for } 3 \text { days }) \\
\text { IVM } \\
\text { (A dose of } 200 \mu \mathrm{g} / \mathrm{kg} \text { at once) }\end{array}$ \\
\hline Metagonimiasis & & $\begin{array}{l}\text { Ingestion of freshwater fish } \\
\text { "Ayu" }\end{array}$ & & $\begin{array}{l}\text { PZQ } \\
(50 \mathrm{mg} / \mathrm{kg} / \text { day for } 1-2 \text { days })\end{array}$ \\
\hline Ascariasis & & & & PP \\
\hline Hookworm infection & & Ingestion of organic vegetables & $\begin{array}{l}\text { Stool examination } \\
(\mathrm{eggs})^{\mathrm{b}}\end{array}$ & (A single dose of $5-10 \mathrm{mg} / \mathrm{kg}$ ) \\
\hline Tapeworm & & $\begin{array}{l}\text { Ingestion of marine fish, beef or } \\
\text { pork }\end{array}$ & & $\begin{array}{l}\mathrm{PZQ}^{\mathrm{c}} \\
\text { (10 } \mathrm{mg} / \mathrm{kg} \text { at one time) } \\
\text { +Laxative }\end{array}$ \\
\hline
\end{tabular}

3. Abdominal symptom-Acute abdomen

\begin{tabular}{|c|c|c|c|c|}
\hline Possible parasitoses & Findings & Remarks & Diagnosis & Treatment \\
\hline Anisakiasis (Stomach) & & & Endoscopically & Pick out \\
\hline $\begin{array}{l}\text { Anisakiasis } \\
\text { (Small intestine) }\end{array}$ & \multirow{2}{*}{$\begin{array}{l}\text { X-p: Ileus } \\
\text { (Eosinophilia) }\end{array}$} & Ingestion of marine fish and squid & \multirow{2}{*}{ Immunodiagnosis } & \multirow{2}{*}{ Symptomatic treatment } \\
\hline $\begin{array}{l}\text { Spiruroid larva } \\
\text { migrans }\end{array}$ & & $\begin{array}{l}\text { Ingestion of small scintillated } \\
\text { squids }\end{array}$ & & \\
\hline $\begin{array}{l}\text { Ascariasis } \\
\text { (ectopic migration) }\end{array}$ & & Ingestion of organic vegetables & Endoscopically & Pick out \\
\hline \multicolumn{5}{|c|}{ 4. Liver or biliary tract lesions } \\
\hline Possible parasitoses & Findings & Remarks & Diagnosis & Treatment \\
\hline Amebiasis & $\begin{array}{l}\text { US, CT, MR: liver abscess with clear } \\
\text { irregular margin }\end{array}$ & $\begin{array}{l}\text { STD } \\
\text { Immunodeficiency (HIV) } \\
\text { Not always including the intesti- } \\
\text { nal lesion }\end{array}$ & $\begin{array}{l}\text { Immunodiagnosis } \\
\text { Detection of } \\
\text { trophozoites in ab- } \\
\text { scess drainage }\end{array}$ & $\begin{array}{l}\text { MNZ } \\
\text { (1,500 mg/day for } 10 \text { days })\end{array}$ \\
\hline Fascioliasis & $\begin{array}{l}\text { US, CT, MR: SOL with irregular margin } \\
(>3-4 \mathrm{~cm}) \\
\text { Eosinophilia }\end{array}$ & $\begin{array}{l}\text { Ingestion of herb or cattle liver } \\
\text { Cattle farmer }\end{array}$ & $\begin{array}{l}\text { Immunodiagnosis } \\
\text { (Detection of } \\
\text { eggs) }\end{array}$ & $\begin{array}{l}\text { TCBZ } \\
\text { (A dose of } 10 \mathrm{mg} / \mathrm{kg} \text { at once) }\end{array}$ \\
\hline
\end{tabular}


(Table 3. continued)

\begin{tabular}{|c|c|c|c|c|}
\hline $\begin{array}{l}\text { A. suum-/T. canis- } \\
\text { VLM }\end{array}$ & $\begin{array}{l}\text { US: Beads sign } \\
\text { CT, MR: Small multiple nodule }(0.5-1.0 \\
\mathrm{cm}) \\
\text { Eosinophilia }\end{array}$ & $\begin{array}{l}\text { Ingestion of chicken/cattle liver } \\
\text { or organic vegetables } \\
\text { History of dog parenting } \\
\text { Lung/Ocular/CNS involvements }\end{array}$ & \multirow{3}{*}{ Immunodiagnosis } & $\begin{array}{l}\text { ABZ } \\
(10-15 \mathrm{mg} / \mathrm{kg} / \text { day for } 4-8 \\
\text { weeks })\end{array}$ \\
\hline Echinococcosis & $\begin{array}{l}\text { US, CT, MR: Poly cystic SOL with ir- } \\
\text { regular margin } \\
\text { Calcification }\end{array}$ & $\begin{array}{l}\text { Origin/Habitat } \\
\text { E. multilocularis: Hokkaido } \\
\text { E. granulosus: Manchuria } \\
\text { CNS (/Lung) involvements }\end{array}$ & & $\begin{array}{l}\text { Surgical resection } \\
\text { ABZ } \\
\text { (Repeated administration of } \\
10-15 \mathrm{mg} / \mathrm{kg} / \text { day for } 4 \text { weeks) }\end{array}$ \\
\hline Paragonimiasis & $\begin{array}{l}\text { Hepatic capsulitis, Calcification } \\
\text { (Eosinophilia) }\end{array}$ & $\begin{array}{l}\text { Ingestion of freshwater crabs or } \\
\text { wild bore } \\
\text { Lung/Skin/CNS involvements }\end{array}$ & & $\begin{array}{l}\text { PZQ } \\
\text { (75 mg/kg/day for } 3 \text { days) }\end{array}$ \\
\hline \multicolumn{5}{|c|}{ 5. Respiratory symptoms or lesions } \\
\hline $\begin{array}{l}\text { Löffler Syndrome } \\
\text { Ascariasis } \\
\text { Hookworm disease } \\
\text { Strongyloidiasis }\end{array}$ & $\begin{array}{l}\text { X-p, CT: Diffuse mottled infiltration } \\
\text { (resemble military tuberculosis or viral } \\
\text { pneumonia) } \\
\text { Eosinophilia }\end{array}$ & $\begin{array}{l}\text { Ingestion of organic vegetables } \\
\text { Origin/Habitat (Okinawa) } \\
\text { Immunodeficiency (HIV, ATL) }\end{array}$ & $\begin{array}{l}\text { Detection of lar- } \\
\text { vae in sputum } \\
\text { Immunodiagnosis }\end{array}$ & $\begin{array}{l}\mathrm{ABZ} \\
(10-15 \mathrm{mg} / \mathrm{kg} / \text { day for } 3 \text { days }) \\
\text { TBZ } \\
(30-50 \mathrm{mg} / \mathrm{kg} / \text { day for } 3 \text { days) } \\
\text { IVM } \\
\text { (A single dose of } 200 \mu \mathrm{g} / \mathrm{kg})\end{array}$ \\
\hline $\begin{array}{l}\text { A. suum-/T. canis- } \\
\text { VLM }\end{array}$ & $\begin{array}{l}\text { X-p, CT: Diffuse mottled infiltration } \\
\text { Eosinophilia }\end{array}$ & $\begin{array}{l}\text { Ingestion of chicken/cattle liver } \\
\text { or organic vegetables } \\
\text { History of dog parenting } \\
\text { Liver/Ocular/CNS involvements }\end{array}$ & Immnunodiagnosis $^{\mathrm{d}}$ & $\begin{array}{l}\text { ABZ } \\
(10-15 \mathrm{mg} / \mathrm{kg} / \mathrm{day} \text { for } 4-8 \\
\text { weeks })\end{array}$ \\
\hline \multicolumn{5}{|l|}{ 6. Skin lesions } \\
\hline Possible parasitoses & Findings & Remarks & Diagnosis & Treatment \\
\hline $\begin{array}{l}\text { Dog hookworm } \\
\text { infection }\end{array}$ & \multirow[t]{5}{*}{ Creeping eruption } & Travel abroad (Resort beach) & Biopsy & $\begin{array}{l}\text { Surgical resection } \\
\text { ABZ } \\
(10-15 \mathrm{mg} / \mathrm{kg} / \text { day for } 3 \text { days) } \\
\text { IVM } \\
\text { (A dose of } 200 \mu \mathrm{g} / \mathrm{kg} \text { at once) }\end{array}$ \\
\hline $\begin{array}{l}\text { Spiruroid larva } \\
\text { migrans }\end{array}$ & & $\begin{array}{l}\text { Ingestion of small scintillated } \\
\text { squids }\end{array}$ & \multirow{4}{*}{$\begin{array}{l}\text { Immunodiagnosis } \\
\text { Biopsy }\end{array}$} & Surgical resection \\
\hline Gnathostomiasis & & $\begin{array}{l}\text { Ingestion of freshwater fish or } \\
\text { snakes }\end{array}$ & & $\begin{array}{l}\text { Surgical resection } \\
\text { ABZ } \\
(10-15 \mathrm{mg} / \mathrm{kg} / \text { day for } 3 \text { days })\end{array}$ \\
\hline Sparganosis & & $\begin{array}{l}\text { Ingestion of chicken, snake or } \\
\text { frog }\end{array}$ & & $\begin{array}{l}\text { Surgical resection }{ }^{\mathrm{e}} \\
\mathrm{PZQ} \\
(75 \mathrm{mg} / \mathrm{kg} / \text { day for } 3 \text { days })\end{array}$ \\
\hline Paragonimiasis & & $\begin{array}{l}\text { Ingestion of freshwater crabs or } \\
\text { wild bore }\end{array}$ & & $\begin{array}{l}\text { PZQ } \\
\text { ( } 75 \mathrm{mg} / \mathrm{kg} / \text { day for } 3 \text { days) }\end{array}$ \\
\hline
\end{tabular}


(Table 3. continued)

\section{CNS symptoms}

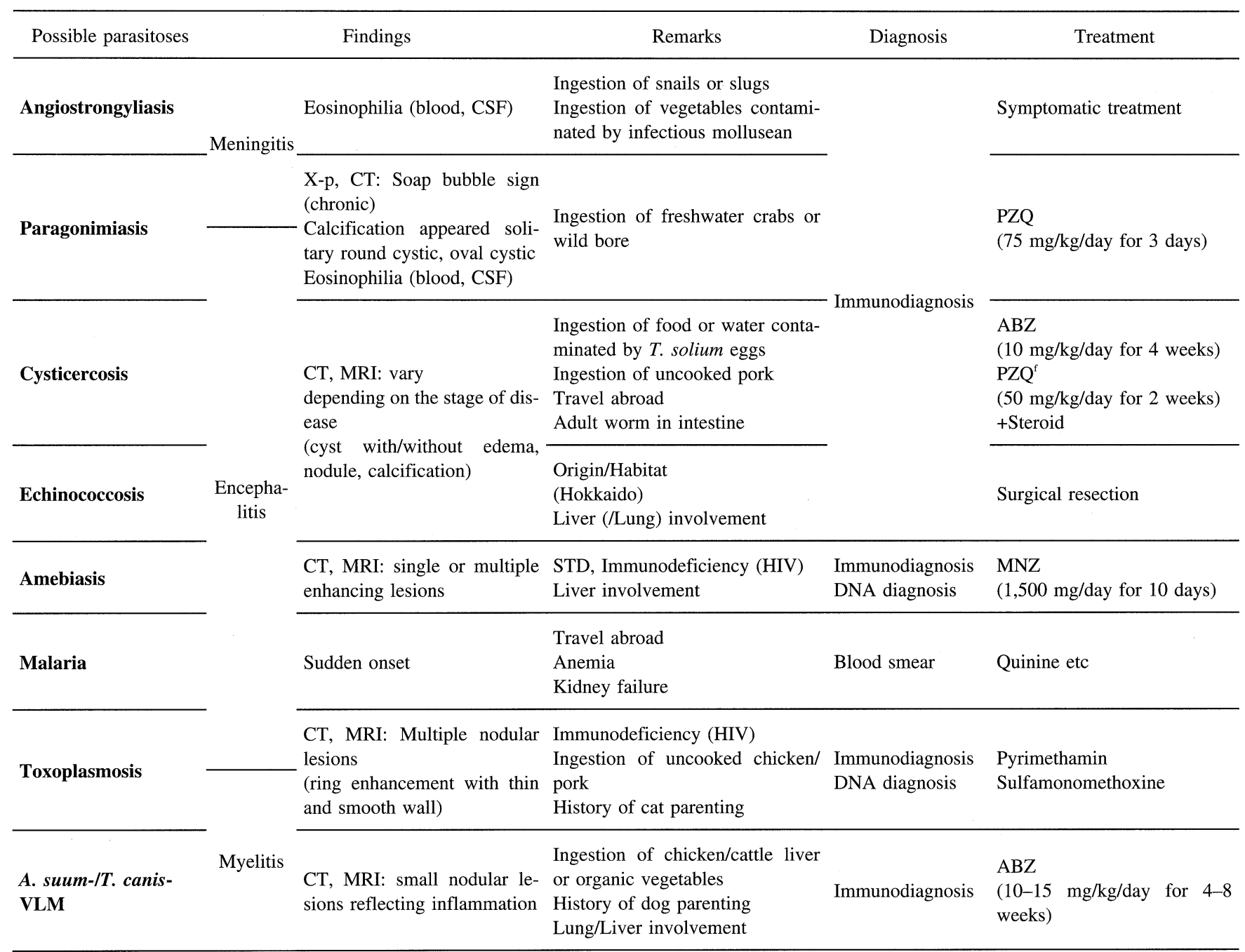

${ }^{a}$ Depending on the patient's state, drug resistance malaria. ${ }^{\mathrm{b}}$ In case of tapeworm infection, most patients have an episode of release of worm segments (proglottids). 'In case of Taenia solium (pork tapeworm) infection, elimination by "Gastrographin” is better for preventing autoinfection. 'In case of inactive dirofilariasis, immunodiagnosis is not always useful. ${ }^{~ I t}$ is important to excise the entire parasites. 'When the adult worm exists in small intestine, worm expulsion by "Gastrographin" should be prior to PZQ treatment for preventing the autoinfection. MNZ: metronidazole, TBZ: thiabendazole, IVM: ivermectin, PZQ: praziquantel, PP: pyrantel pamoate, TCBZ: triclabendazole, ABZ: albendazole, DEC: diethylcarbamazine.

often misdiagnosed as malignant diseases resulting in excessive diagnostic tests or unnecessary surgery (2). These facts remind of us the vital importance of the correct diagnosis for parasitic diseases. Therefore we outlined the clinical features and tips for diagnosis and treatment of representative parasitic diseases in Japan to facilitate a better understanding of the parasitic diseases for correct diagnosis and more appropriate treatments (Table 3 ).

\section{Fever}

When patients with FUO (fever of unknown origin) have a history of traveling abroad especially to tropical developing countries, we have to think of the possibility of malaria, dengue fever or typhoid fever (23). Particularly Plasmodium falciparum infection called malignant malaria progresses rapidly and shows a high mortality rate within a week or so. Since red blood cells infected with $P$. falciparum tend to cause obstruction in small vessels of brain and kidney, the patient show acute cerebral symptoms or renal failure (22). It should be noted that the fever pattern is not always typical even in the patients infected with $P$. vivax or $P$. malariae. It is important for the diagnosis of malaria to detect the malaria parasite in blood smear by Giemsa staining (pH 7.2) (Fig. 2). When fluorescence microscopy is available, rapid diagnosis of malaria can be obtained by acridine orange staining (24). Quinine and sulfadoxine/pyrimethamine are the commercially available anti-malarial drugs in Japan. However, the first choice of drugs depends on the patient's state. A combi- 


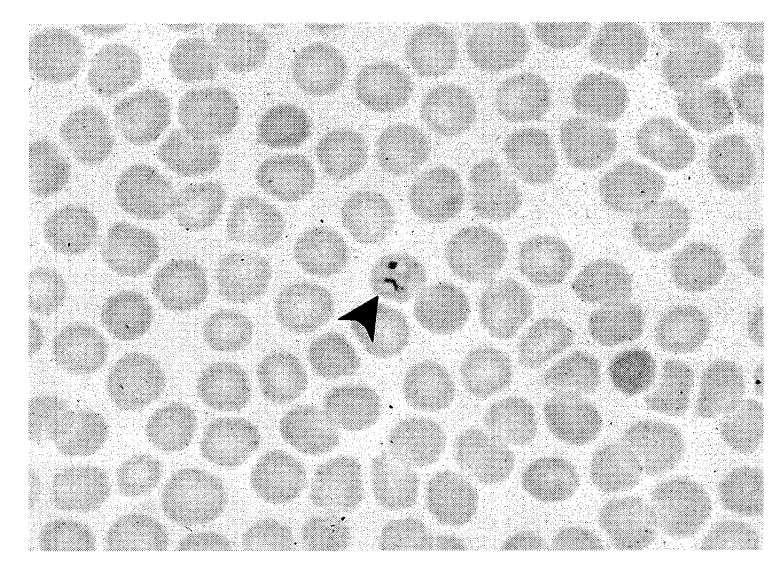

Figure 2. Direct demonstration of $P$. falcipalum in blood smear (arrowhead, Giemsa staining, pH 7.2).

nation of drugs having different pharmacological actions or having targeting the different of malaria parasite stages is necessary for complete cure. In addition drug-resistant malaria parasite are gradually increasing in almost all endemic areas (22). Various anti-malarial drugs are available from the Japan Health Science Foundation Orphan Drug Study Group under approval of Ministry of Health, Labor and Welfare (Table 4). Detailed information such as dosage and administration or pharmacological actions of drugs are available in the Study Group website (http://www.ims.u-tokyo.ac.jp/ didai/orphan/index.html).

\section{Abdominal symptom: diarrhea}

Some parasitic infections cause diarrhea as seen in Table 3.2. Mucous and bloody stool is characteristic of intestinal entoamebiasis. Massive infection with Metagonimus or giardiasis, cryptosporidiosis and strongyloidiasis in immunocompromised hosts may present severe diarrhea leading to protein-loosing enteropathy $(23,25)$. Therefore when a patient with severe diarrhea due to infection with opportunistic parasites is found, it is important to search for the underlying disease leading immunodeficiency. Definitive diagnosis can be obtained by direct demonstration of parasite trophozoites, cysts, oocysts, larva or eggs in feces.

Thiabendazole (TBZ) was the only approved therapeutic drug for strongyloidiasis in Japan. This drug usually requires at least a 3-day dosage but has a high frequency of side effects which interfere with compliance $(26,27)$. Instead of TBZ, ivermectin (IVM), a newly developed anti-Strongyloides drug, is now commercially available. This drug is significantly effective with a single dose of $200 \mu \mathrm{g} / \mathrm{kg}$ without severe side effects (28). Standard treatment protocol for cryptosporidiosis in patients with HIV has not been established yet. Although there are a few reports suggesting that azithromycin, clarithromycin or roxithromycin were effective for cryptosporidiosis in patients with HIV, the efficacy of these drugs are still controversial and reports of ineffective cases exist. Thus, the development of effective anti-
Table 4. Orphan Drug List Available from the Japan Health Science Foundation Orphan Drug Study Group Under Approval of Ministry of Health, Labor and Welfare $^{\mathrm{a}}$

\begin{tabular}{lll}
\hline \multicolumn{1}{c}{ Drug } & \multicolumn{1}{c}{ Formula } & \multicolumn{1}{c}{ Indication } \\
\hline Chloroquine sulfate & Tablet & Malaria \\
Atovaquone/Proguanil & Tablet & Malaria \\
Artesunate & Tablet/Suppository & Malaria \\
Quinine glyconate & Injectable & Malaria \\
Primaquine phosphate & Tablet & Malaria \\
Metronidazole & Injectable & Entoamebiasis \\
Diloxanide furoate & Tablet & Entoamebiasis \\
Sodium stibogluconate & Injectable & Leishmaniasis \\
Ivermectin & Tablet & Onchocerciasis \\
& & (Strongyloidiasis) \\
Triclabendazole & Tablet & Scabies \\
& & Fascioliasis \\
Ribavirin & Tablet & Paragonimiasis \\
Suramin & & Viral Hemorrhagic \\
Melasoprol & Injectable & Fever \\
Eflornithine & Injectable & Trypanosomiasis \\
\hline
\end{tabular}

${ }^{a}$ For dosage and administration refer to Study Group website (http://www.ims.u-tokyo.ac.jp/didai/orphan/index.html).

Cryptosporidium drugs is urgently needed (29). In case of severe intestinal entoamebiasis with peritonitis, metronidazole (MNZ) div is available from the Orphan Drug Study Group.

\section{Abdominal symptom: acute abdomen}

Some parasitic diseases cause acute abdomen (Table 3.3). Among them, gastric anisakiasis is probably the most prevalent one. Typical anisakiasis develops 5-6 hours after the ingestion of marine fish, mackerels or squids. Principle of diagnosis and treatment of this disease is to pick out the worms endoscopically (30). In the case of intestinal anisakiasis, patients may present ileus. Recently, Spirurina Type X larva infection has been emerged and patients develop ileus and/or creeping eruption (11). The major source of infection with Spirurina Type X larva is small schintillant squids. Special anthelminthic drugs are not found for Anisakis or Spirurina, and spontaneous cure of these diseases is often observed by conservative treatment alone. Therefore when the patient with acute abdomen is strongly suspected of having these parasitic infections based on the eating history, excessive examination or unnecessary surgery should be avoided.

As an extremely rare case, colonic ileuses due to nodular lesions caused by Gnathostoma migration was reported previously (31). Acute abdomen due to ectopic migration to the bile duct or pancreatic duct of Ascaris lumbricoides are often reported, suggesting that this classic parasite still exists sporadically in Japan (4). Massive infections with A. lumbri- 

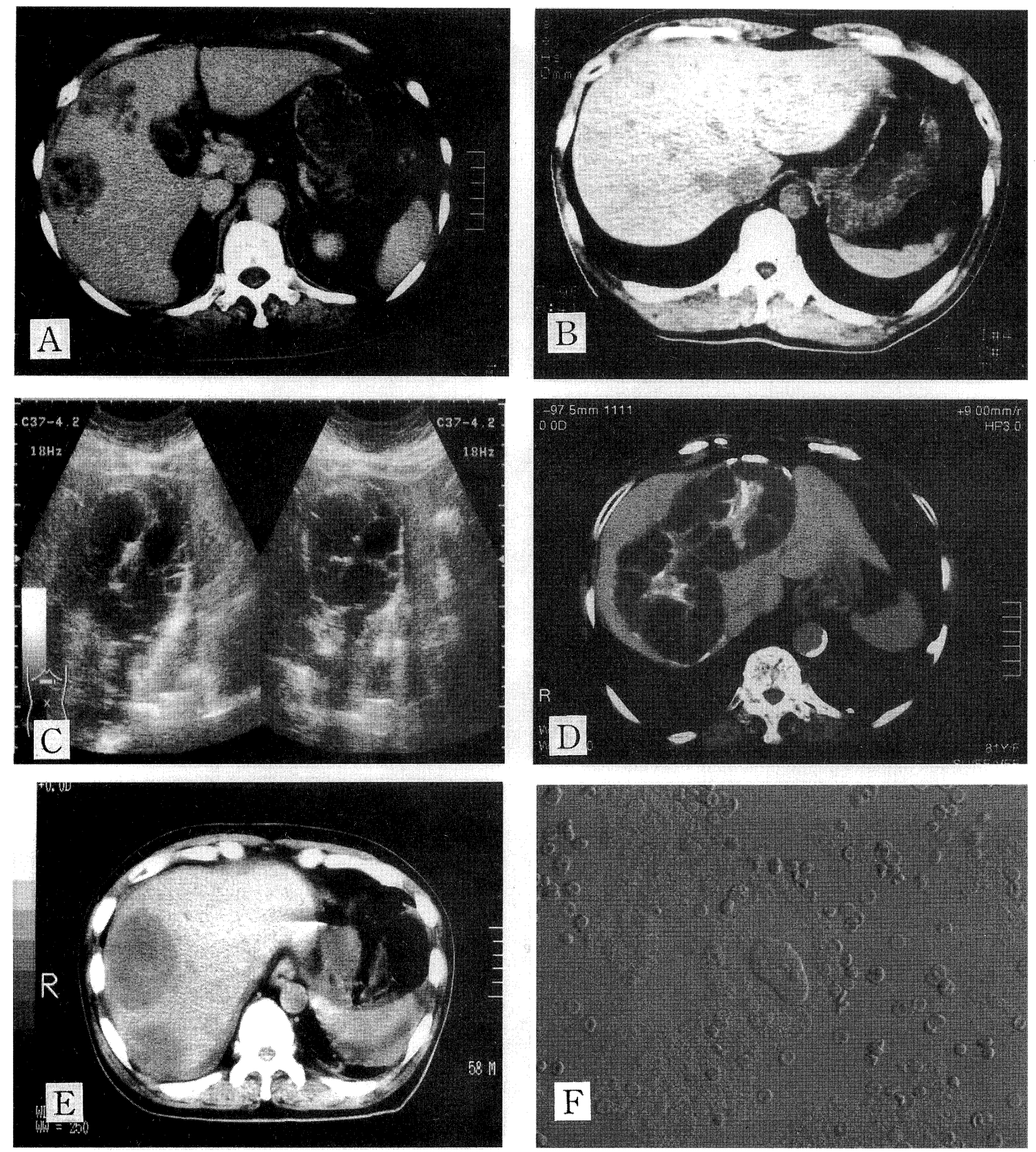

Figure 3. Liver lesions in various parasitic diseases. These findings are similar to those of hepatocellular carcinoma, cholangiocellular carcinoma or metastatic tumor; Abdominal CT of fascioliasis (A), A. suum-VLM (B), abdominal echo and CT of echinococcosis granulose (C, D) and CT of entoamebiasis (E). E. histolytica trophozite in liver abscess drainage (F).

coides cause bolus obstruction in the intestine (32).

\section{Abdominal symptom: lesions in the liver or biliary tract}

The liver and biliary tract are involved in some parasitic diseases (Table 3.4). Bile duct is the target of Fasciola and Clonorchis. Ascaris, Toxocara and hookworm larvae are carried into liver via portal blood stream. Notably these liveraffecting parasitic diseases are often manifested as space occupying lesions and misdiagnosed as malignant diseases such as hepatocellular carcinoma, cholangiocellular carcinoma or metastatic tumor because of similarity on diagnostic imaging (Fig. 3). Fascioliasis and A. suum-/T. canis-VLM are frequently associated with peripheral blood eosinophilia. Thus clinicians should be aware of the possibility of parasitic diseases especially when patients with liver lesions reveal eosinophilia. Immunodiagnostic methods such as multipledot ELISA to detect antibody against parasites are particu- 
lary valuable for the rapid screening to diagnose these diseases (33).

Fascioliasis cases in Japan have been found mostly around small-scale cattle farms. Over 100 cases were found by 1992 (34) and more cases have been added year after year (35, 36). Praziquantel (PZQ) is the only available drug for chemotherapy for fascioliasis. However, the efficacy of PZQ for fascioliasis remains controversial, in spite of its broad trematodicidal spectrum (36). Recently, triclabendazole (TCBZ) is recommended by WHO as an essential drug against fascioliasis (37), and TCBZ tablets for human use have become available since April 2001 through the Orphan Drug Study Group (38).

Larva migrans due to infection with $T$. canis is famous for its preferential ocular involvement in children in Western countries. The major route of infection is thought to be a direct oral infection from pet puppies. However in Japan the number of adult patients is far greater than that of children (16). Similarly the majority of A. suum-VLM patients in Japan are middle-aged males. In Japan, both Toxocara-VLM and A. suum-VLM are thought to occur mainly by ingesting chicken/cattle liver or organic vegetables contaminated by parasite eggs (16). Because of the nature of migration of $A$. suum and T. canis larvae, the liver (Fig. 3B) and lungs (Fig. 4E) are the commonest sites affected in A. suum-/T. canisVLM $(39,40)$. It should be noted that $A$. suum as well as $T$. canis migrate occasionally into the CNS (41). Standard protocol for chemotherapy on VLM has not yet determined. Albendazole (ABZ) is assumed to be effective for VLM, but needs 4-8 weeks of continuous administration and has side effects causing transient liver dysfunction.

Echinococcosis is a slowly progressive and chronic disease caused by infection with Echinococcus multilocularis or E. granulosus. The former infection to humans is often lethal because of its metastatic nature and is emerging in Hokkaido (42). Whereas the latter infection is benign and only a few cases were sporadically found in Japan (Fig. 3C, D) (43). Though the diagnosis can be achieved by the serological test and findings on ultrasonography, habitat profile of the patient is the most important information to suspect of echinococcosis (44). Surgical resection is the only way to treat echinococcosis. Benzimidazole derivatives such as ABZ or mebendazole (MBZ) seem to be effective, however it is difficult to obtain complete cure (44). Thus early diagnosis and subsequent surgical treatment is essential to cure this disease.

Entoamebiasis is emerging in Japan, especially as STD. Though the parasite primarily causes colitis (amebic dysentery), abscess in the liver (Fig. 3E) is not rare. Amebic liver abscess is diagnosed directly by a demonstration of trophozoites in the drainage fluid from the abscess (Fig. 3F) or indirectly by immunodiagnostic methods (33). Intestinal involvement is not always evident. MNZ is a drug of choice. In severe cases, MNZ div is available from the Orphan Drug Study Group.

Although Paragonimus is a lung-seeking trematode, its juvenile worms migrate from the small intestine to the lung through several tissue/organs including peritoneal organs. Thus, the liver, peritoneal cavity, abdominal skin, or urogenital organs are occasionally affected (45). Most of these patients having ectopic infection are asymptomatic and found by chance in a post-operative histopathological examination under the diagnosis of non-parasitic disease $(46,47)$. In patients with active ectopic paragonimiasis, immunodiagnosis is useful and, regardless of the site affected, patients can be cured by PZQ. Recently we encountered a case of active hepatic capsulitis due to infection with $P$. westermani (48).

Schistosomiasis japonicum and clonorchiasis are well known causes of liver cirrhosis, which sometimes becomes liver cancer. Once liver cirrhosis has developed, anthelminthic treatment is ineffective. Therefore, early diagnosis and treatment is essential for these diseases. No new cases of schistosomiasis and few cases of clonorchiasis have been reported in Japan. However, it should be noted that these diseases still exist all over the world especially in Asian countries and a few imported cases have been reported.

\section{Respiratory symptoms or lesions}

Possible parasitic diseases presenting respiratory symptoms or lesions are summarized in Table 3.5. Paragonimiasis patients often present respiratory symptoms with eosinophilia. Since radio-imaging appearances of paragonimiasis are variable, it is difficult to distinguish this disease from lung cancer, tuberculosis, or fungal infections (Fig. 4A-D) (45). It should be noted that despite remarkable chest radiological findings in the lung parenchyma and/or pleural cavity, about $20 \%$ of paragonimiasis patients are asymptomatic; the presence of lung lesion happens to be discovered by chest X-ray examination at a regular health screening (45). Recently, we demonstrated that pleurisy with a high degree of eosinophilia (>20\%) is characteristic of the early stage of paragonimiasis, whereas parenchymatous lesions with relatively low eosinophilia $(\sim 10 \%)$ were characteristic of the late stage (49). Immunodiagnosis is quite useful for the diagnosis of paragonimiasis because egg detection rates in sputum or bronchoscopic aspirates were less than $50 \%$ (45). In the very early stage of this disease, detection of parasite-specific IgM rather than IgG antibody is useful and should be considered (49). Pulmonary paragonimiasis can be treated by oral administration of PZQ (75 mg/kg/day for 3 days) with an almost $100 \%$ cure rate (45).

A. lumbricoides, hookworm and Strongyloides infection cause Löffler's syndrome, an acute eosinophilic pneumonia with tracheitis. Pathogenesis of this syndrome is thought to be due to hypersensitive reaction to migrating larvae. Severe symptoms such as cough, wheezing and dyspnea last for 710 days and usually resolve spontaneously when larvae migrate out of the lungs (50). When the disease status is worsening rapidly or patients show the signs of septicemia and/or CNS involvement, we should consider the possibility of disseminated strongyloidiasis in which drastic increase in 

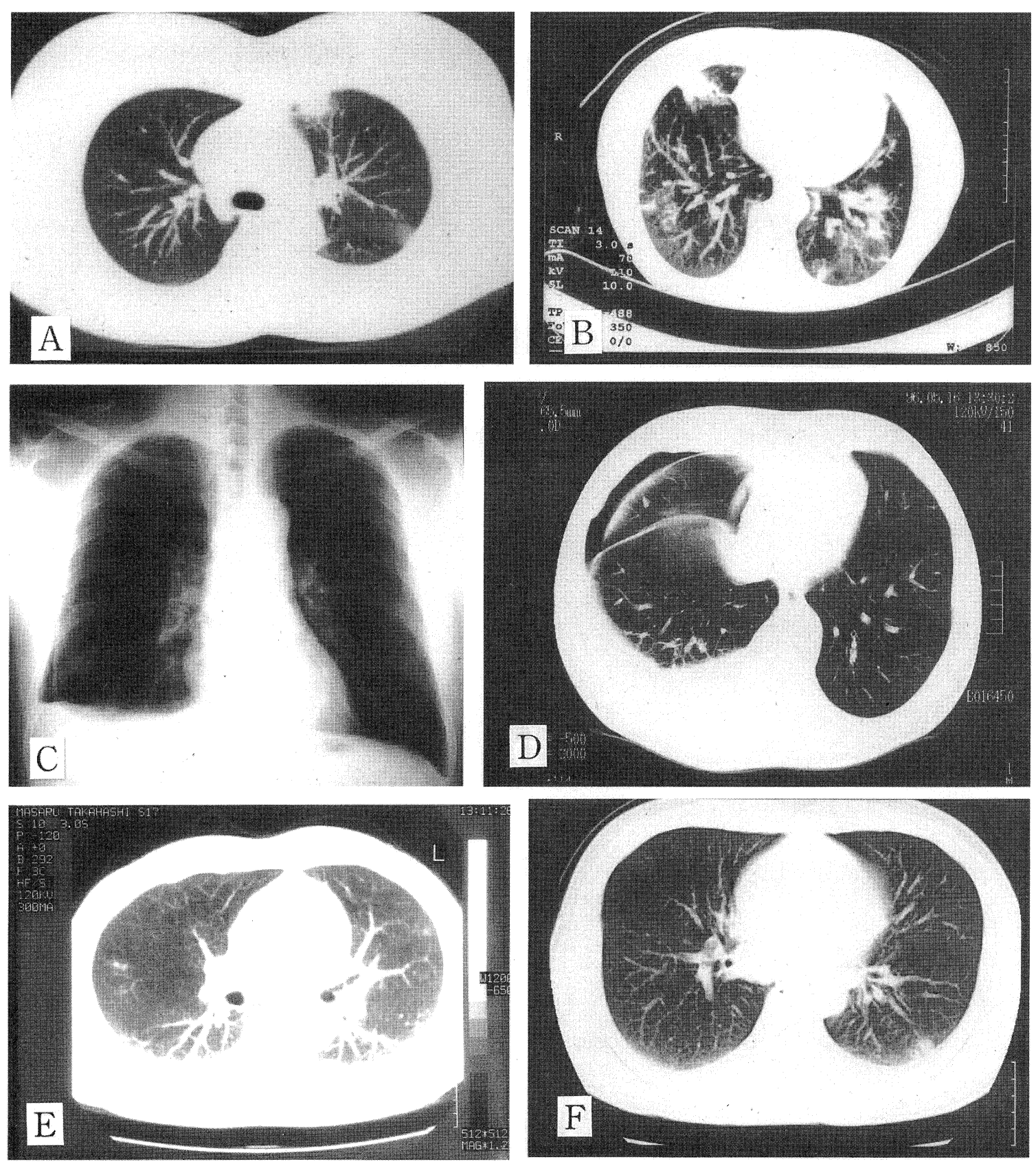

Figure 4. Lung lesions in various parasitic diseases. Variance of paragonimiasis on chest radiography; nodular (A), mixed pattern (B), pleural effusion and pneumothrax (C, D). Chest CT findings of A. suum-VLM (E) and dirofilariasis (F). (A-D: Reprinted from Clinics in Chest Medicine, 23, Nakamura-Uchiyama F et al, "Paragonimiasis: A Japanese perspective", 409-420, Copyright 2002, with permission from Elsevier Science).

number of Strongyloides larvae occurs from autoinfection associated with the invasion of intestinal bacteria. Larvae can be seen in the sputum smear of disseminated strongyloidiasis patients. Such a condition is frequently seen in patients with immunodeficiency (51). Whenever we see disseminated strongyloidiasis patients in Japan, we must consider the possibility of ATL/HTLV-1 infection.

In cases of A. suum-/T. canis-VLM presented with respi- ratory symptoms, lesions may be seen not only in the lungs (Fig. 4E) but also in the liver, eyes and CNS. As the nature of ascarid larvae, they migrate first into the liver via portal blood flow, then migrate into lungs via blood stream, and then disseminated by systemic circulation. Thus it is important to perform systematic examinations of all possible organs affected in patients with A. suum-/T. canis-VLM (16). Treatment for VLM has been described in the liver lesion 

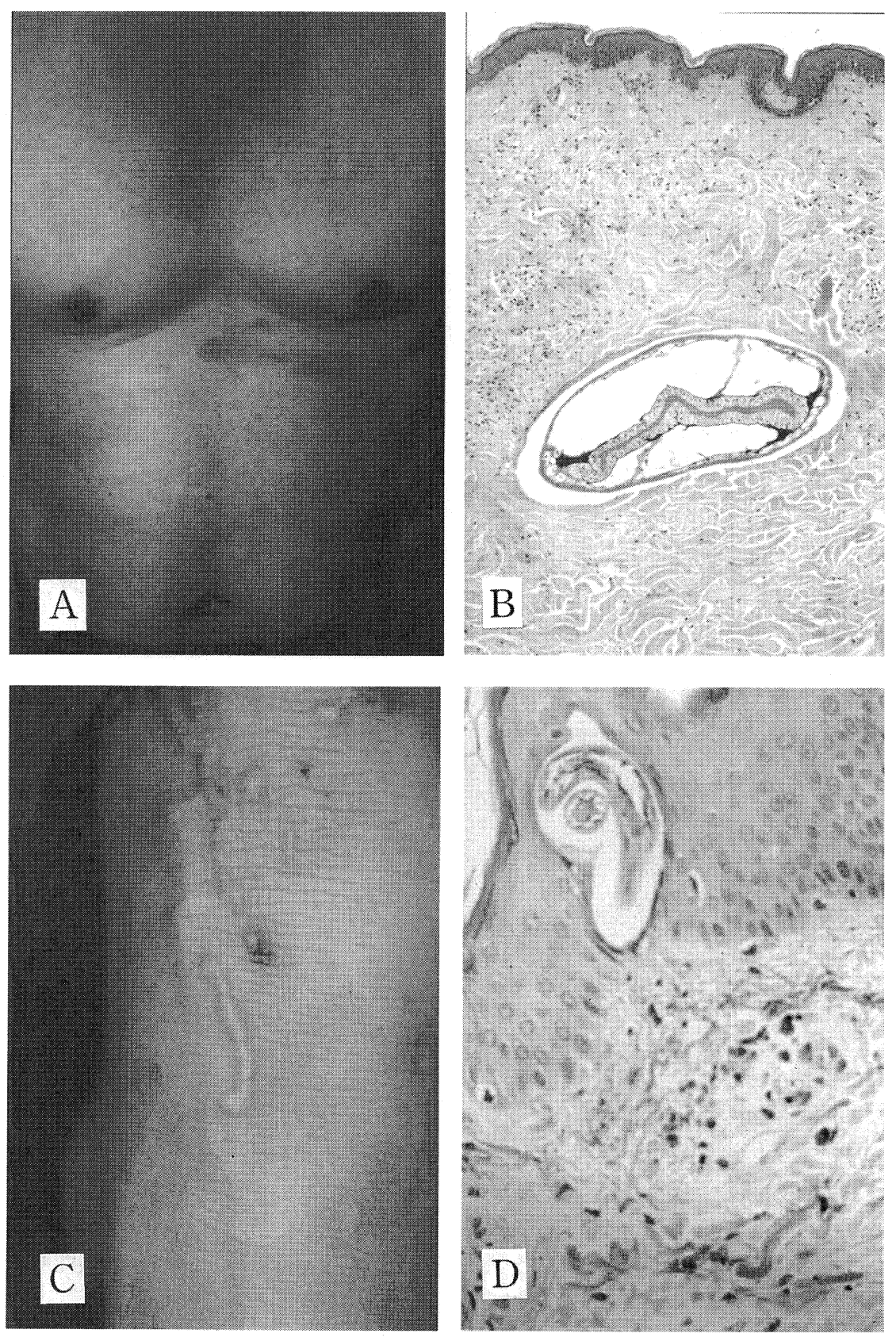

Figure 5. Skin lesions. Creeping eruption due to infection with Gnathostoma (A) and larval dog hookworm (C). Gnathostoma exists in deep site $(B, \times 25)$ whereas larval hookworm is in the epidermis $(\mathrm{D}, \times 200)$.

section above.

Dirofilaria immitis is known as a zoonotic parasite causing pulmonary dirofilariasis in humans. Typical dirofilariasis is asymptomatic and characteristic of coin lesion in the chest radiography (Fig. 4F). Therefore, patients with pulmonary dirofilariasis have been often misdiagnosed as malignancy and received unnecessary examinations and/or surgical treatments. We have reported three cases of pulmonary diro- filariasis successfully diagnosed with serological tests (52). Diethylcarbamadine (DEC) is a recommended drug for pulmonary dirofilariasis, though it is ineffective for chronic cases.

As extremely rare cases, various parasites such as Gnathostoma (53), Spirometra $(54,55)$ and Anisakis (56) unexpectedly migrate into the pleural cavity causing pleuropulmonary lesions. All of these cases were serologically 

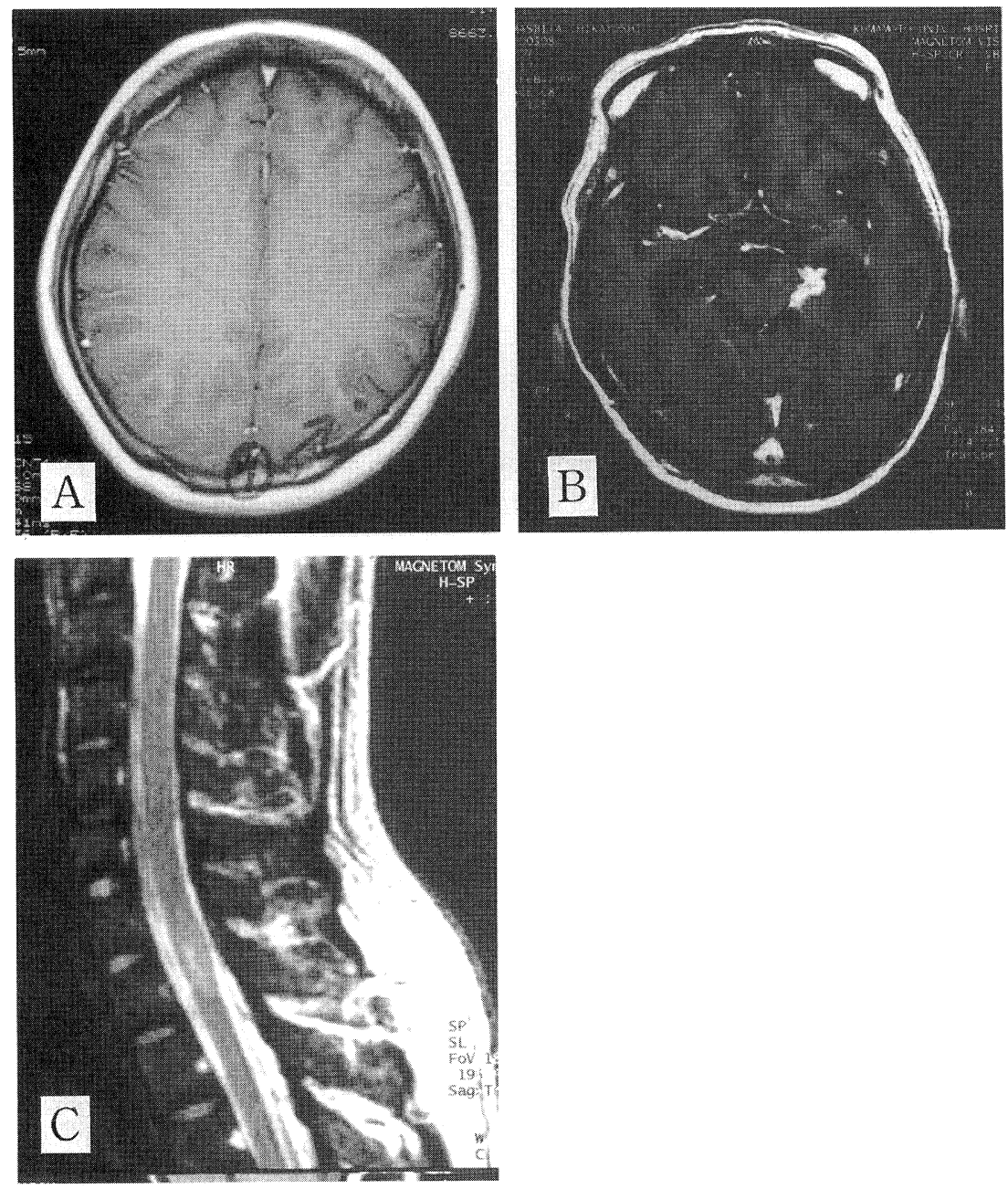

Figure 6. CNS lesions in various parasitic diseases. Various lesions of neurocysticercosis depending on the stage of the diseases (A, B). MRI findings of spinal lesion of A. suum-VLM (C). (B: Reprinted from Rinsho Shinkeigaku, 42, Nakajima $M$ et al, "A case of neurocysticercosis suggestive of a reinfection, 20 years after the initial onset", 18-23, 2002, with permission from Japanese Society of Neurology. C: Reprinted from J Neurol Neurosurg Psychiatry, 70, Osoegawa $M$ et al, "Localised myelitis caused by visceral larva migrans due to Ascaris suum masquerading as an isolated spinal cord tumor", 265-266, 2001, with permission from BMJ publishing Group).

diagnosed. In cases of pulmonary sparganosis (Sparganum mansoni, larval form of $S$. erinaceieuropaei, infection), PZQ treatment at the dose of $75 \mathrm{mg} / \mathrm{kg} /$ day for 3 days is highly effective. At the present, standard protocol for pleuropulmonary nematodiasis due to ectopic migration of Gnathostoma or Anisakis larvae has not been established yet. Symptomatolytic treatment with anti-inflammatory drugs is the only practical way to treat these patients.

\section{Mobile skin lesions}

Mobile skin lesions strongly suggest the presence of parasitic infection, and causative parasites can be predicted, though not definitely, from the type of skin lesions (creeping eruption or mobile nodular lesion) and the eating history (Table 3.6) (57). Gnathostomiasis (Fig. 5A, B) occurs by ingestion of freshwater fish (brook trout, domestic or imported loach and snakehead fish) or snakes $(12,13,15)$ and presents both types of lesions depending on its species (58). Sparganosis due to infection with the $S$. mansoni, larval form of $S$. erinaceieuropaei, occurs by ingestion of raw or undercooked chicken, snake or frog meat and presents with a slowly moving nodular lesion (14). Skin involvement is well known in paragonimiasis (45). Spirurina Type X larvae were identified to cause creeping eruption more often than ileus (11). Recently we reported 7 cases of creeping eruption due to infection with dog hookworm larvae overseas (Fig. 5C, D) (59). As can be seen in those pictures, creeping eruption due to dog hookworm larvae is usually limited to the epidermal layer.

The surgical removal of the larva is the best way for treatment as well as leading to definitive diagnosis. However the rate of resection is usually low. Thus immunodignosis is im- 
portant for the diagnosis of these diseases (57). Several reports have documented that $\mathrm{ABZ}$ is effective for gnathostomiasis and larval animal hookworm infection $(58,59)$. Recently Wear et al (60) recommended a single oral dose of IVM (12 mg/adult or $200 \mu \mathrm{g} / \mathrm{kg} \mathrm{B.W}$. at once) for hookworm infection.

\section{CNS symptoms}

Possible parasitic diseases affecting CNS are summarized in Table 3.7. Human infection with Angiostrongylus cantonensis occurs by ingesting contaminated snails and slugs, or green vegetables, and appears as eosinophilic meningitis/meningoencephalitis. Though the severity of symptoms depends on worm burden, the patients may present cranial nerve involvement (especially facial palsy), ocular manifestations (mainly diplopia), psychosis, and sensory impairment in addition to headache with fever (61). This parasite is widely distributed in Okinawa but sporadically found around the international trading harbors of main lands of Japan (62). Some cases of Angiostrongylus infection by ingesting raw slugs as medical treatment have been reported $(18,19)$. Although the standard protocol has not yet been established, consecutive administration of $\mathrm{ABZ}$ is reported to be effective for treatment of angiostrongyliasis.

Larval form of Taenia solium, Cysticercus cellulosae, frequently causes cerebral, ocular, and subcutaneous cysticercosis (63). CT and MRI findings of neurocysticercosis vary depending on the stage of the disease (Fig. 6A, B) (64). Infection to humans occurs by ingestion of food or water contaminated with $T$. solium eggs or by cysticercicontaminated pork meat. The eggs release the larvae that invade the intestinal mucosa, enter blood vessels, and travel to various organs and tissues, where they develop into cycticerci and cause human cysticercosis. When the cysticerci are ingested, they develop into adult $T$. solium in the intestine. Then the worm segments (proglottids) rupture and release eggs in the intestine. Cysticercosis results from intestinal autoinfection (63). It is important to determine whether the patients with neurocysticercosis have adult worms in their intestine. This is because if patients have adult $T$. solium infection in their intestine, treatment of cysticercosis with PZQ leads to the autoinfection by the rupture of the proglottids. Thus, worm expulsion by gastrographin must be preceded to the administration of PZQ in cysticercosis co-infected with adult $T$. solium. Treatment of cysticercosis itself can be done successfully by the administration of PZQ or ABZ with steroid.

As a rare form of neuroparasitoses, A. suum-/T. canisVLM occasionally involves CNS including the spinal cord (Fig. 6C) $(41,65)$. CNS is a target organ of acquired toxoplasmosis, especially in the compromised hosts like AIDS/HIV infection, as well as congenital toxoplasmosis. Not only Entoameba histolytica but also Naegleria fowleri causes amebic meningoencephalitis. Recently the first case of primary amebic meningoencephalitis due to $N$. fowleri was reported in Japan (66). While entoamebic abscess in
CNS can be treated successfully with MNZ, chemotherapy for meningoencephalitis due to free-living amoeba like Naegleria has not been established.

\section{Conclusion: We Are Still Living in This Wormy World}

From the global point of view, helminth infections are still threatening to human health and current numbers of helminth infections are estimated as about 4,500 million which number is beyond Stoll's estimate in 1964 (67). Parasitic diseases in Japan will remain to exist and recent rapid globalization is a warning alarm us to pay more attention not only to domestic but also to the imported parasitic diseases in Japan. We should be aware of the possibility of parasitic diseases because we are still living in this wormy world .

Acknowledgments: This work is supported in part by a Grant-in-Aid for Scientific Research KH42074 from the Ministry of Health, Welfare and Labor. We give special thanks to Naoki Arizono, MD, PhD (Department of Medical Zoology, Kyoto Prefectural University of Medicine) and Masahide Yoshikawa, MD, PhD (Department of Parasitology, Nara Medical University) for their valuable advice for this study. We also thank the attending physicians for providing the diagnostic imaging. The excellent technical assistance of Ms Ayumi Tanaka for immunodiagnosis is gratefully acknowledged.

\section{References}

1) Kagei N, Hayashi S. Parasitic disease control in Japan. in: Progress of Medical Parasitology in Japan (Japanese Edition). Vol. 7. Otsuru M, Kamegai S, Hayashi S. Eds. Meguro Parasitological Museum, Tokyo, 1999: 647-668.

2) Nawa $Y$, Noda $S$, Nakamura-Uchiyama F, Ishiwata K. Current status of food-borne parasitic zoonoses in Japan. Southeast Asian J Trop Med Public Health 32 Suppl 2: 4-7, 2001.

3) Nakamura-Uchiyama F, Nawa Y. Diagnosis for parasitic diseases with reference to healthcare economics. Clin Parasitol 13: 25-27, 2002 (in Japanese).

4) Arizono N. Parasitology and parasitic disease in Japan. Proceedings of the 1st Congress of Federation of Asian Parasitologists, Chiba, 2000: 97-105.

5) Uchiyama F, Morimoto Y, Nawa Y. Re-emergence of paragonimiasis in Kyushu, Japan. Southeast Asian J Trop Med Public Health 30: 686691, 1999.

6) Maruyama H, Nawa Y, Noda S, Mimori T, Choi WY. An outbreak of visceral larva migrans due to Ascaris suum in Kyushu, Japan. Lancet 347: 1766-1767, 1996.

7) Nozaki T. Current problems of amebiasis in Japan and recent advances in amebiasis research. Jpn J Infect Dis 53: 229-237, 2000.

8) Kuroki T, Watanabe $Y$, Asai $Y$, et al. An outbreak of waterborne Cryptosporidiosis in Kanagawa, Japan. Kansenshogaku Zasshi (J J A Inf D) 70: 132-140, 1996 (in Japanese, Abstract in English).

9) Yamamoto W, Urabe K, Takaoka $M$, et al. Outbreak of cryptosporidiosis after contamination of the public water supply in Saitama Prefecture, Japan, in 1996. Kansenshogaku Zasshi (J J A Inf D) 74: 518-526, 2000 (in Japanese, Abstract in English).

10) Hashimoto A, Kunikane S, Hirata T. Prevalence of Cryptosporidium oocysts and giardia cysts in the drinking water supply in Japan. Water Res 36: 519-526, 2002.

11) Hasegawa H. Spirurinasis. in: Progress of Medical Parasitology in Japan (Japanese Edition). Vol. 7. Otsuru M, Kamegai S, Hayashi S. Eds. Meguro Parasitological Museum, Tokyo, 1999: 511-520. 
12) Ogata K, Imai J, Nawa Y. Three confirmed and five suspected human cases of Gnathostoma doloresi infection found in Miyazaki prefecture, Kyushu. Jpn J Parasitol 37: 358-364, 1988.

13) Ishiwata $K$, Nakao $H$, Nose $R$, et al. Gnathostomiasis in frog-eating snakes from Japan. J Wildl Dis 33: 877-879, 1997.

14) Marty AM, Neafie RC. Diphyllobothriasis and Sparganosis. in: Pathology of Infectious Diseases. Vol. 1 Helminthiases. Meyers WM Ed. AFIP, Washington DC, 2000: 165-183.

15) Kurokawa M, Ogata K, Sagawa S, Miyaoka Y, Noda S, Nawa Y. Cutaneous and visceral larva migrans due to Gnathostoma doloresi infection via an unusual route. Arch Dermatol 134: 638-639, 1998.

16) Ishiwata $K$, Nawa $Y$. Parasitic zoonosis-Larva migrans caused by ascarid parasite of animals - Antibiotics and Chemotherapy 17: 120126, 2001 (in Japanese).

17) Okamoto M, Miyake Y, Shouji S, et al. A case of severe paragonimiasis miyazakii with lung and skin lesions showing massive egg production in sputum and faeces. Jpn J Parasitol 42: 429-433, 1993.

18) Kojima $S$, Hata $H$, Kobayashi $M$, et al. Eosinophilic meningitis: a suspected case of angiostrongylosis found in Shizuoka Prefecture, Honshu, Japan. Am J Trop Med Hyg 28: 36-41, 1979.

19) Nakazawa K, Kato Y, Sakai H. A case of eosinophilic meningitis due to Angiostrongylus cantonensis. Kansenshogaku Zasshi (J J A Inf D) 66: 998-1001, 1992 (in Japanese, Abstract in English).

20) Obara A, Nakamura-Uchiyama F, Nawa Y. Paragonimiasis westermani cases recently found among foreigners in Japan. Clin Parasitol 13: 136138, 2002 (in Japanese).

21) Orlandi PA, Chu DMT, Bier JW, et al. Parasites and the food supply. Food Tech 56: 72-81, 2002.

22) Fujii T, Kimura M. Management of severe malaria. Antibiotics and Chemotherapy 14: 803-811, 1998 (in Japanese).

23) Ohnishi K. Clinical symptoms and examination for parasitic diseases. Rinsho Kensa 43: 1583-1588, 1999 (in Japanese).

24) Kawamoto F, Billingsley PF. Rapid diagnosis of malaria by fluorescence microscopy. Parasitol Today 8: 69-71, 1992.

25) Ichiki $Y$, Tanaka $T$, Haraguchi $Y$, et al. A case of severe metagonimiasis with abdominal symptoms. Jpn J Parasitol 39: 72-74, 1990.

26) Grove DI. Treatment of strongyloidiasis with thiabendazole: an analysis of toxicity and effectiveness. Trans R Soc Trop Med Hyg 76: 114 118, 1982.

27) Oyakawa $T$, Kuniyoshi $T$, Arakaki $T$, et al. New trial with thiabendazole for treatment of human strongyloidiasis. Kansenshogaku Zasshi (J J A Inf D) 65: 304-310, 1991 (in Japanese, Abstract in English).

28) Nakamura-Uchiyama F, Hiromatsu K, Nawa Y. Ivermectin. Iyaku Journal (Med Drug J) Suppl.: 131-137, 2003 (in Japanese).

29) Ohonishi K. Cryptosporidiasis in patients infected with HIV. Clin Parasitol 13: 45-47, 2002 (in Japanese).

30) Yoshida S. Anisakis. Illustrated Human Parasitology. 6th ed. Nanzando, Tokyo, 2002: 96-101.

31) Seguchi $K$, Matsuno $M$, Kataoka $H$, et al. A case report of colonic ileus due to eosinophilic nodular lesions caused by Gnathostoma doloresi infection. Am J Trop Med Hyg 53: 263-266, 1995.

32) Oshikawa $K$, Todaka $S$, Horii $Y$, et al. A case report of bolus intestinal obstruction due to massive infection with Ascaris lumbricoides. Jpn J Parasitol 41: 42-45, 1992.

33) Nawa $Y$, Nishimura K, Matsumoto H. Practical methods for detection of parasite-specific IgG antibody. Medical Technology 29: 11911196, 2001 (in Japanese).

34) Kagei N. Current status of fascioliasis in Japan. Infect Agents Surv Rep 14: 101-102, 1993 (in Japanese).

35) Maruyama $H$, Noda $S$, Mimori $T$, et al. Fascioliasis cases recently found in the southern part of Kyushu District, Japan. Jpn J Parasitol 45: 247-254, 1996.

36) Kodama K. Human fascioliasis: comparison of a fasciolicidal effect of bithionol and praziquantel. Kansenshogaku Zasshi (J J A Inf D) 71: 1162-1167, 1997 (in Japanese, Abstract in English).

37) Savioli L, Chitsulo L, Montresor A. New opportunities for the control of fascioliasis. WHO Bull 77: 300, 1999.

38) Ishii $Y$, Nakamura-Uchiyama F, Nawa Y. A praziquantel-ineffective fascioliasis case successfully treated with triclabendazole. Parasitol Int 51: 205-209, 2002.

39) Maruyama H, Kobayashi T, Tomita M, et al. Immunologically diagnosed toxocariasis with bilateral pleural effusion. Jpn J Parasitol 44: 248-253, 1995.

40) Maruyama H, Noda S, Choi WY, et al. Fine binding specificities to Ascaris suum and Ascaris lumbricoides antigens of the sera from patients of probable visceral larva migrans due to Ascaris suum. Parasitol Intern 46: 181-188, 1997.

41) Inatomi $Y$, Murakami $T$, Tokunaga $M$, Ishiwata $K$, Nawa $Y$, Uchino $M$. Encephalopathy caused by visceral larva migrans due to Ascaris suum. J Neurol Sci 164: 195-199, 1999.

42) Kamiya S, Oku Y. Echinococcus (1) Biology. in: Progress of Medical Parasitology in Japan (Japanese Edition). Vol. 7. Otsuru M, Kamegai S, Hayashi S. Eds. Meguro Parasitological Museum, Tokyo, 1999: 275295.

43) Kojima H, Miyaji K, Hongou S, et al. A case of cystic hydatid disease of the liver. Clin Parasitol 13: 118-121, 2002 (in Japanese).

44) Sato N, Uchino J. Echinococcus (2) Diagnosis and treatment. in: Progress of Medical Parasitology in Japan (Japanese Edition). Vol. 7. Otsuru M, Kamegai S, Hayashi S. Eds. Meguro Parasitological Museum, Tokyo, 1999: 297-309.

45) Nakamura-Uchiyama F, Mukae H, Nawa Y. Paragonimiasis: a Japanese perspective. Clin Chest Med 23: 409-420, 2002.

46) Nabeshima $K$, Inoue $T$, Sekiya $R$, et al. Intrahepatic paragonimiasisa case report. Jpn J Parasitol 40: 296-300, 1991.

47) Shimao $Y$, Koono M, Ochiai A, et al. A case of intraperitoneal granuloma due to occult infection with Paragonimus sp. Jpn J Parasitol 43: 315-317, 1994.

48) Sasaki M, Kamiyama T, Yano T, Nakamura-Uchiyama F, Nawa Y. Active hepatic capsulitis caused by Paragonimus westermani infection. Intern Med 41: 661-663, 2002.

49) Nakamura-Uchiyama F, Onah DN, Nawa Y. Clinical features of paragonimiasis cases recently found in Japan: parasite-specific immunoglobulin $\mathrm{M}$ and $\mathrm{G}$ antibody classes. Clin Infect Dis 32: e171-175, 2001.

50) Neafie RC, Marty AM. Ascariasis. In: Pathology of infectious diseases. in: Pathology of Infectious Diseases. Vol. 1 Helminthiases. Meyers WM Ed. AFIP, Washington DC, 2000: 397-409.

51) Kishyaba T. Disseminated strongyloidiasis. in: Strongyloides and strongyloidiasis in Japan. Shiroma Y, Sato Y Eds. Kyushu Univ Press, Fukuoka, 1997: 55-78 (in Japanese).

52) Suzumiya J. Nawa Y. Three cases of pulmonary dirofilariasis found in Miyazaki prefecture. Jpn J Parasitol 39: 67-71, 1990.

53) Miyamoto N, Mishima K, Nagatomo K, et al. A case report of serologically diagnosed pulmonary gnathostomiasis. Jpn J Parasitol 43: 397-400, 1994.

54) Tanaka S, Maruyama $H$, Ishiwata $K$, et al. A case report of pleural sparganosis. Parasitol Intern 46: 73-75, 1997.

55) Ishii $\mathrm{H}$, Mukae $\mathrm{H}$, Inoue $\mathrm{Y}$, et al. A rare case of eosinophilic pleuritis due to sparganosis. Inten Med 40: 783-785, 2001.

56) Matsuoka $H$, Nakama $T$, Kisanuki $H$, et al. A case report of serologically diagnosed pulmonary anisakiasis with pleural effusion and multiple lesions. Am J Trop Med Hyg 51: 819-822, 1994.

57) Nakamura-Uchiyama F, Nawa Y. Parasitic (protozoan \& helminthic) diseases. Sogo Rinsho 51 Suppl.: 685-692, 2002 (in Japanese).

58) Nawa $\mathrm{Y}$, Ishiwata $\mathrm{K}$, Maruyama $\mathrm{H}$, et al. Food-borne parasitic diseases. Clin Infect Chemother 3: 39-42, 1997 (in Japanese).

59) Nakamura-Uchiyama F, Yamasaki E, Nawa Y. One confirmed and six suspected cases of cutaneous larva migrans caused by overseas infection with dog hookworm larvae. J Dermatol 29: 104-111, 2002.

60) Wear DJ, Meyers WM, Neafie RC. Creeping eruption. in: Pathology of Infectious Diseases. Vol. 1 Helminthiases. Meyers WM Ed. AFIP, Washington DC, 2000: 367-372.

61) Marty AM, Meyers WM, Neafie RC. Angiostrongyliasis cantonensis. 


\section{NAKAMURA-UCHIYAMA et al}

in: Pathology of Infectious Diseases. Vol. 1 Helminthiases. Meyers WM Ed. AFIP, Washington DC, 2000: 373-384.

62) Nishimura K. Angiostrongyliasis cantonensis. in: Progress of Medical Parasitology in Japan (Japanese Edition). Vol. 7. Otsuru M, Kamegai S, Hayashi S. Eds. Meguro Parasitological Museum, Tokyo, 1999: 389408.

63) Neafie RC, Marty AM, Johnson LK. Taeniasis and cysticercosis. in: Pathology of Infectious Diseases. Vol. 1 Helminthiases. Meyers WM Ed. AFIP, Washington DC, 2000: 117-136.

64) Noujaim SE, Rossi MD, Rao SK, et al. CT and MR imaging of neurocysticercosis. Am J Roentogenol (AJR) 173: 1485-1490, 1999.

65) Osoegawa M, Matsumoto $\mathrm{S}$, Ochi $\mathrm{H}$, et al. Localised myelitis caused by visceral larva migrans due to Ascaris suum masquerading as an isolated spinal cord tumor. J Neurol Neurosurg Psychiatry 70: 265-266, 2001.

66) Sugita Y, Fujii T, Hayashi I, et al. Primary amebic meningoencephalitis due to Naegleria fowleri: an autopsy case in Japan. Pathol Int 49: 468470, 1999.

67) Crompton DW. How much human helminthiasis is there in the world? J Parasitol 85: 397-403, 1999. 